\title{
THE CHARACTERISTIC OF THE ENGINE QUALITIES OF THE STUDENTS OF TECHNICAL INSTITUTE OF III FUNCTIONAL HEALTH GROUP (SPECIAL MEDICAL GROUP)
}

Prosvirina L.N. ${ }^{1}$, Kolokoltsev M.M. ${ }^{1}$, Kolchanova M.A. ${ }^{1}$, Cieslicka Miroslawa ${ }^{2}$, Stankiewicz Blazej ${ }^{2}$

National Research Irkutsk State Technical University, Russia ${ }^{1}$

Kazimierz Wielki University in Bydgoszcz, Poland ${ }^{2}$

Annotation. Purpose: the study of the dynamics of engine qualities in the students of III functional health group (special medical group) dependent on age taking into account the frequency of occupations by physical culture for the correction of the program of their physical training. Material: the physical condition is evaluated among 467 students at the age from 18 to 21 year. Observation is carried out in the dynamics of the instruction of students at the university from 1 through 5 semesters. Results: installed age characteristics of physical readiness of students, depending on the frequency of physical training. It is shown that the passage to the single-time in the week occupations by physical culture reliably decreases their physical condition. The features of the dynamics of the physical fitness of students. Conclusions: monitoring the physical fitness of students can be considered as a factor in strengthening the pedagogical orientation of physical education of youth. Should pay particular attention to the development of motor abilities missing with appropriate exercise. Students are encouraged to use the self-study managed to maintain the required physical condition, as well as the mandatory maintenance of a diary of self-control.

Keywords: student, university, physical, preparedness, monitoring, physical, culture.

\section{Introduction}

Leading problem of the present time is protection of human health. Modern society puts health, psychological comfort, high workability and healthy reproduction of on one of first places. Without solution of these tasks stable economic and political development of country, as well as social and cultural prosperity, are impossible [5, 7, 8].

Recent years attention to students' health has been increasing and its is connected with society's care of specialists' physical condition, with trouble of their morbidity in process of professional training and resulting workability $[1,2,4,20]$. Preservation of health of educational process's participants is one of important problems of higher professional education and of different branches in medicine. Against this background, seeking of ways for health improvement and increase of workability; increase of functional abilities and adaptation to training of future highly qualified specialists also become rather important $[3,12]$.

Many scientists regard physical education as significant factor I formation and rehabilitation of youth's health [3, 6]. In this case physical health is regarded as one of natural genetically programmed, non-medical and effective factors of youth's health improvement $[17,18,21]$.

At present time at physical culture lessons more individual evaluation of students' physical fitness is required, which would be the base of discipline "physical culture". It will permit to clearly understand weak sides of development of students' motion and functional abilities, to correct curriculums in HEEs and, thus, to weaken negative aspects of students' adaptation to new educational environment [9].

Variety of deviations in health condition, different levels of physical fitness of students set special requirements to physical culture in special health groups (SHG), which imply more individual approach to physical exercises [10]. In this connection there appears a task of working out and foundation of differential approach to selection of optimal loads, considering motivations to self-perfection in interconnection with students' psycho-emotional and motion specificities [7].

A number of authors $[4,5,6,8]$ note that it is necessary to control indicators of physical fitness as important component of children's teenagers and youth's health. In other countries this problem has been studied rather substantially $[13,14,15,16,19]$. However, characteristics of special health group students' motion abilities have not been studied completely.

Purpose, tasks of the work, material and methods

The purpose of the work: characterize age dynamic of girl students of special health group, considering frequency of physical culture training, for correction of physical culture training program.

Materials and methods: we tested 467 girl students (18-21 years old age) of National research Irkutsk state technical university, who were members of special health group (SHG). Our research was conducted in the course of girl students' studying from $1^{\text {st }}$ to $5^{\text {th }}$ semester $(01.10 .2011,01.05 .2012,01.10 .2012,01.05 .2013,01.11 .2013)$. For evaluation of girls' motion characteristics we used tests, worked out by All-Russia scientific-research institute of physical culture [11]. For evaluation of quickness we used test - 20 meters run (sec.); for strength and power endurance of girdle - hanging (sec.) and pressing ups (times); for speed endurance of muscles, bending torso, - torso rising (times); for flexibility - torso bending (cm); for dynamic strength of lower limbs - long jump from the spot (cm); for general endurance - 1000 meters run (minutes, sec.). Material was registered in special record of the research. By primary materials we formed computer data base; calculation of indicators was fulfilled with the help of applied programs «Statistica $6.0 »$.

(c) Prosvirina L.N., Kolokoltsev M.M., Kolchanova M.A.,

Cieslicka Miroslawa, Stankiewicz Blazej, 2015

http://dx.doi.org/10.15561/20755279.2015.0107 
We calculated mean arithmetic value of indicators (M), mean square deviation (s) and standard error (m). In our work we used parametrical methods of material's processing, considering normal Gauss distribution of quantitative characteristics in all age groups. Estimation of confidence of mean values of independent samples was carried out with Student's t- criterion. Differences between indicators with $\mathrm{P}<0.05$ were accepted as statistically confident.

\section{Results of the research}

Research during 5 semester permitted to determine that in test 20 meters from walking (see fig.1) there was improvement by the end of the research - from 3. $58 \pm 0.04$ to $3.49 \pm 0.04$ sec. $(\mathrm{P}<0.05)$.

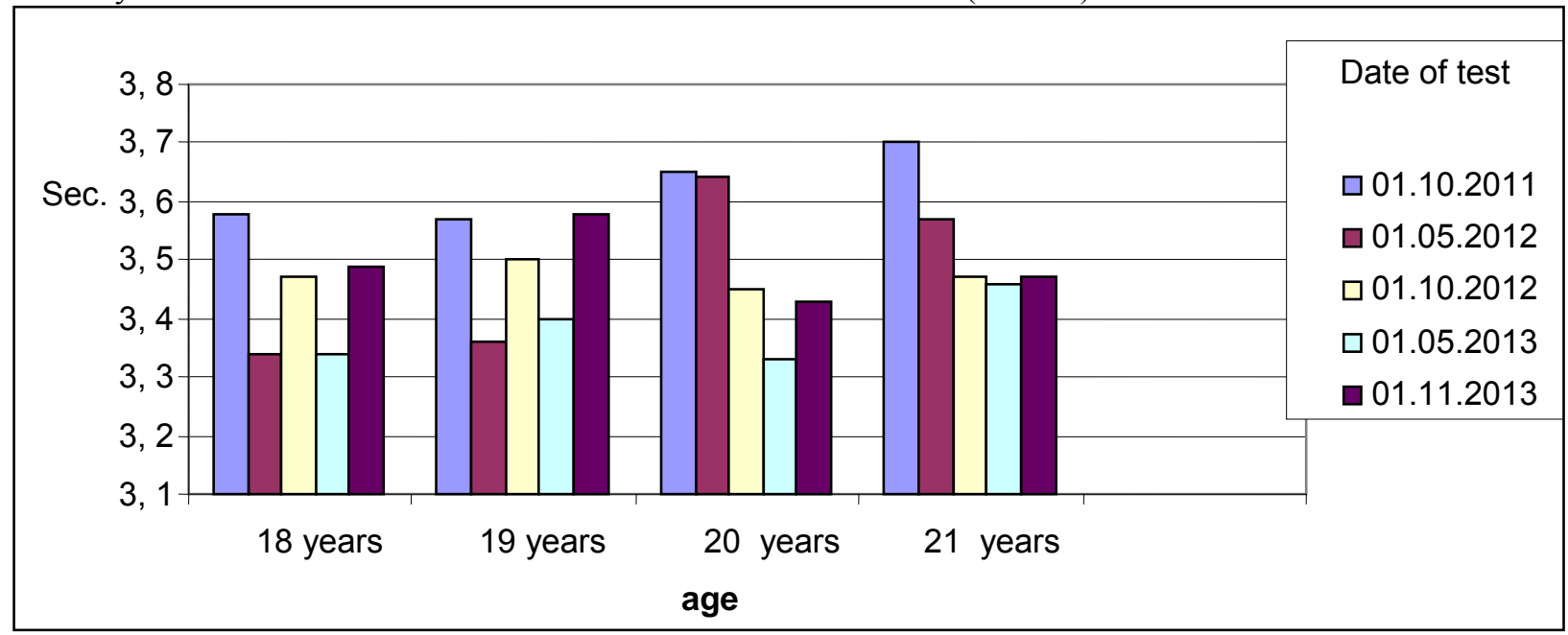

Fig.1. Dynamic of indicators in test 20 meters run from walking

In 19 years we registered improvement of this test result in 2, 3 and 4 semesters. With it, the best result was at the end of academic year of $2^{\text {nd }}$ semester $-3.36 \pm 0.03$ sec. However, by fifth semester we noticed significant worsening up to $3.58 \pm 0.06 \mathrm{sec}$. that approximately corresponds to $1^{\text {st }}$ semester's result. It, in our opinion, is connected with passing of $3^{\text {rd }}$ year students to "once a week" trainings.

20 years old girl students showed confident positive changes of the indicator by the end of $3^{\text {rd }}$ semester; test result improved from $3.64 \pm 0.04 \mathrm{sec}$. to $3.45 \pm 0.05$ (by $5.2 \%$ ); by the end of $4^{\text {th }}$ semester - up to $3.33 \pm 0.04$ sec. (by $8.5 \%$ ). Then there happens certain worsening of result up to $3.43 \pm 0.03 \mathrm{sec}$., and its is, probably, is connected with organization of "once a week" trainings of physical culture.

In older group (21 years) we registered rather high increment of results in this test. By the end of $2^{\text {nd }}$ semester it improved by $3.5 \%$ (from $3.70 \pm 0.06$ to $3.57 \pm 0.04$ ) and by $5^{\text {th }}$ semester - by $6.2 \%$ (up to $3.47 \pm 0.05 \mathrm{sec}$.).

In dynamic of general endurance (see fig.2) we did not determined positive results (test 1000 meter run). In our opinion it is connected with insufficient application of physical loads, oriented on development of this quality, in physical culture trainings.

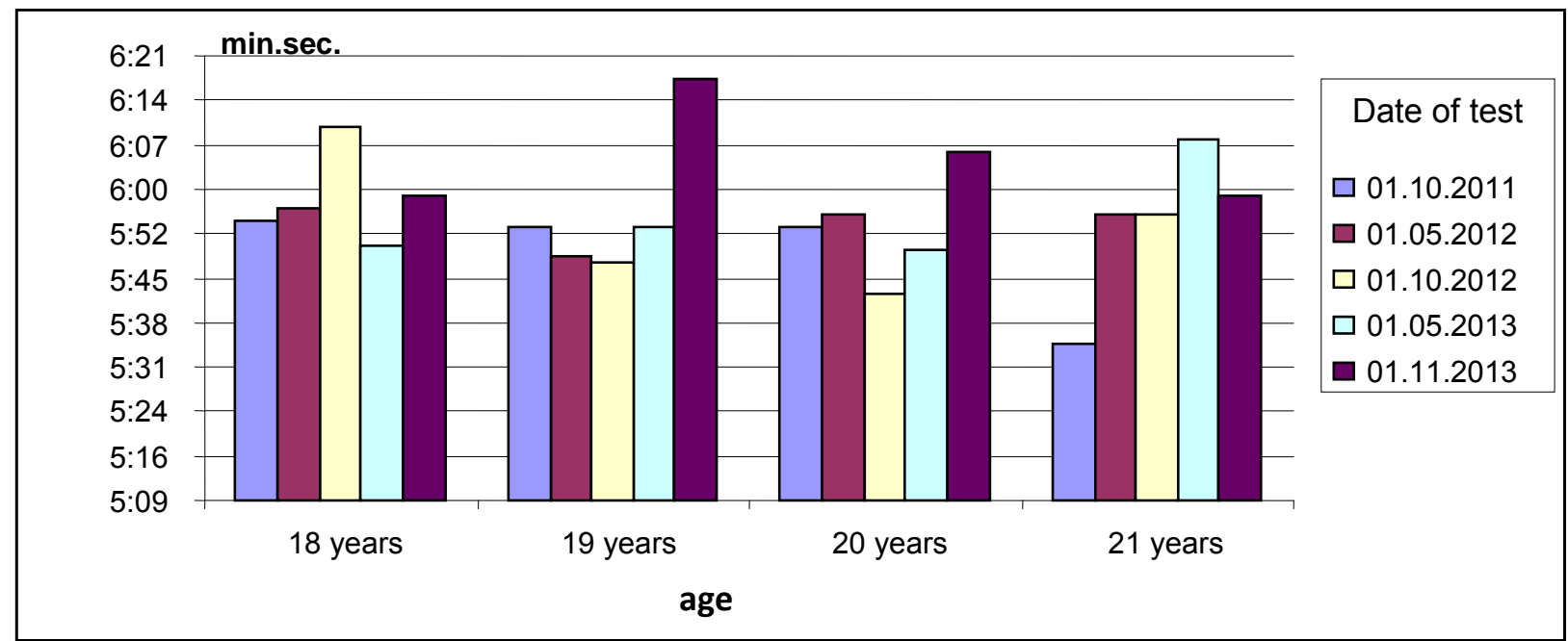

Fig.2.. Dynamic of indicators in test 1000 meters run 
In one of strength qualities (hanging on bent arms) we registered the most expressed positive dynamic of indicators, connected with frequency of physical culture trainings in HEE (see fig. 3).

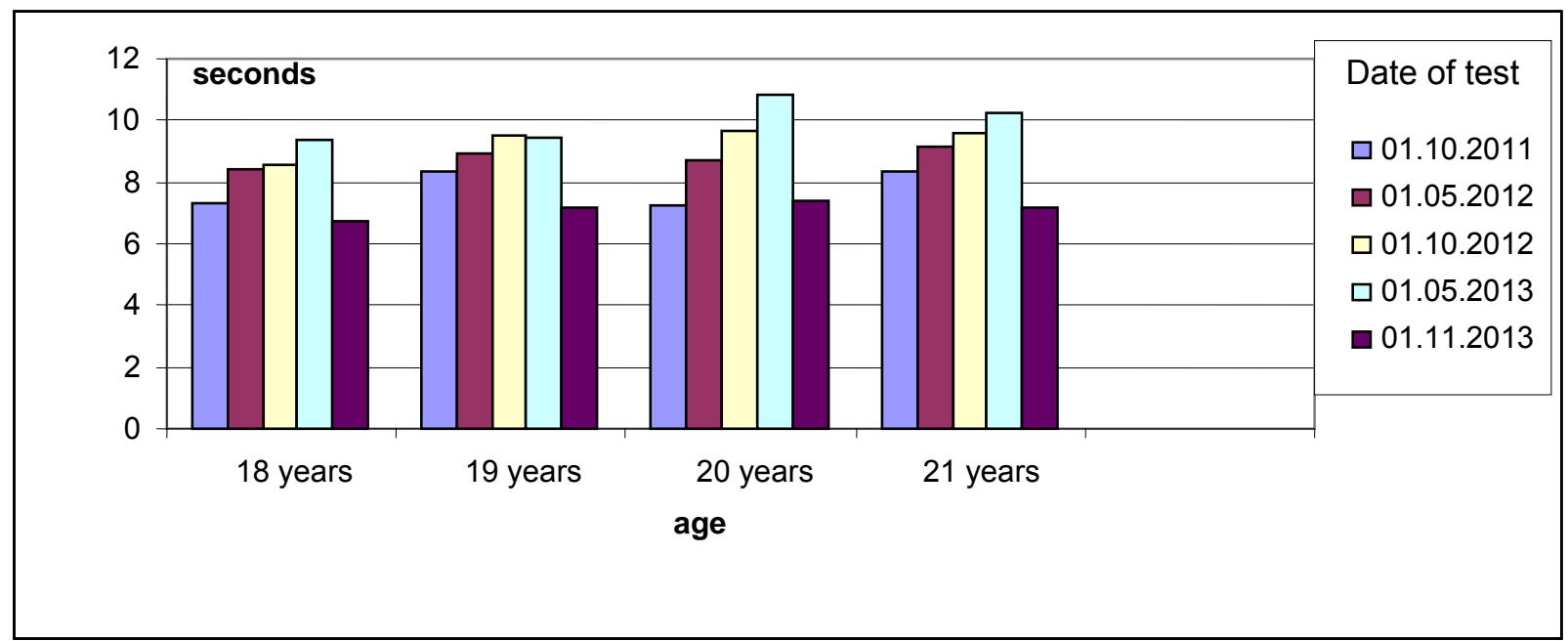

Fig.3. Dynamic of indicators in test "hanging on bent arms"

As it is seen in the figure in all tested age groups there was increment of indicator by May 2013, when girls were $2^{\text {nd }}$ year students and attended physical culture lessons twice a week. With passing to "once a week" trainings and after summer vacations (testing in November 2013) we registered confident reduction of test results in all age groups.

Approximately the same dynamic of indicators was registered in other power test - pressing ups (see fig.4).

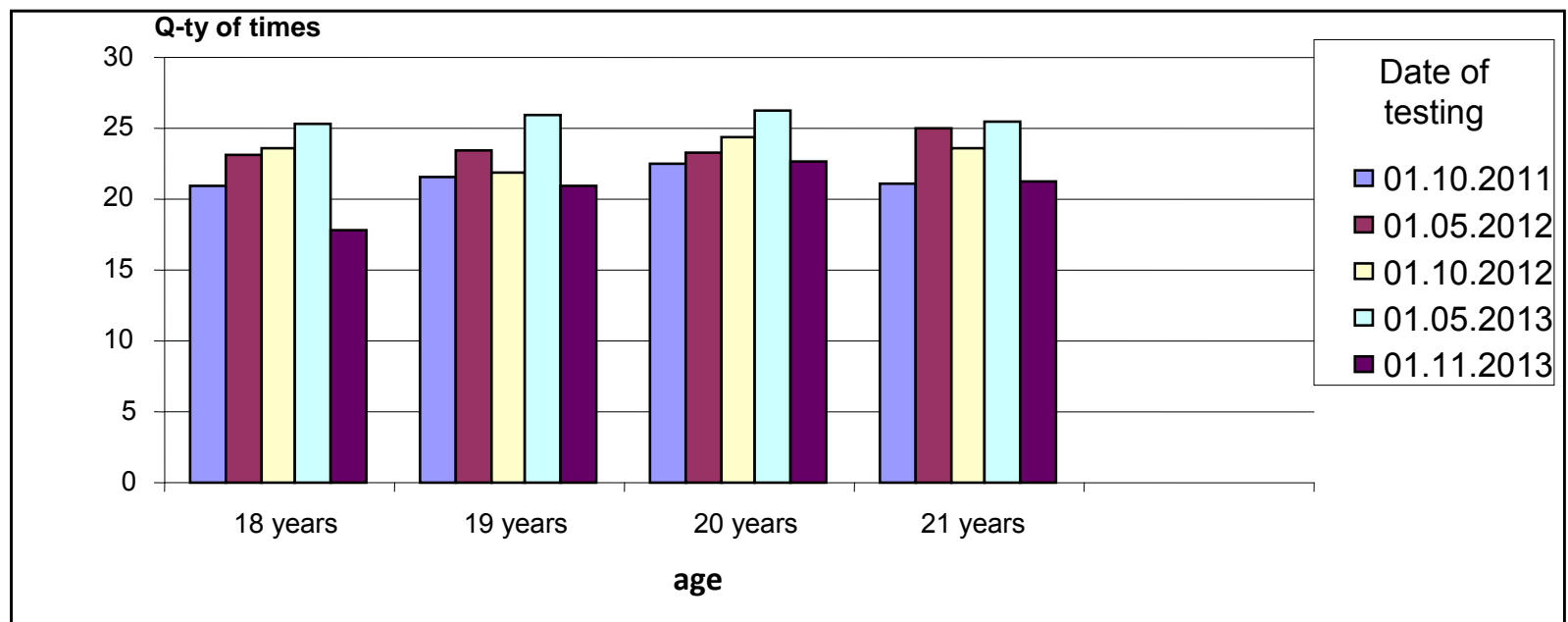

Fig.4. Dynamic of indicators in test "pressing ups"

In this test we registered confident increment of indicator in all tested ages, providing physical lessons were twice a week and reduction of results with passing to "once a week" lessons $(\mathrm{P}<0.05)$, (for third year students). Worsening of characteristics was registered by $41.9 \%$ in age of 18 years old (from $25.31 \pm 0.54$ to $17.83 \pm 0.58$ times) and by $18,8 \%$ in 19 years old age (from $24.94 \pm 0.65$ to $20.99 \pm 0.65$ times). In other ages reduction was not so significant - 9. 6-10.8\%.

In test "torso rising" during 30 seconds (see fig.5) we did not register positive dynamic in indicators. In our opinion the reason is weak condition of abdomen muscles, connected with insufficient using of appropriate exercises in discipline "physical culture". 


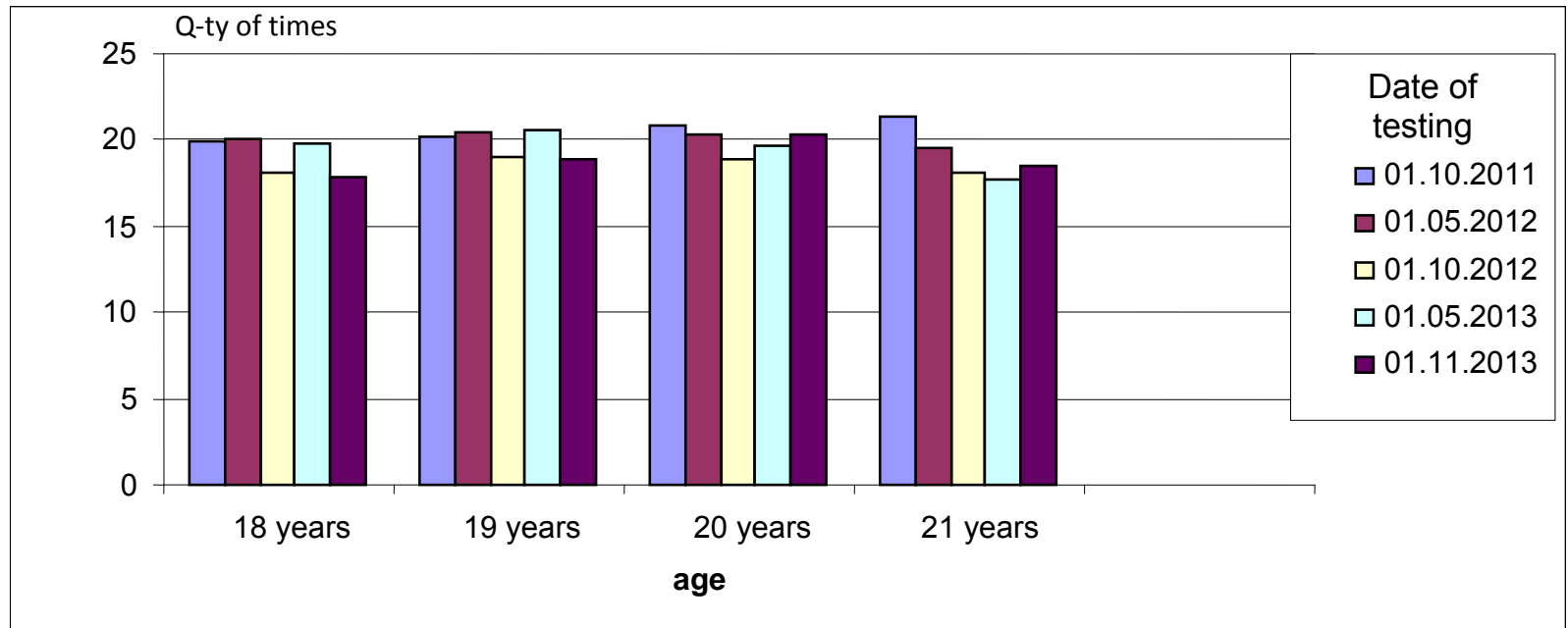

Fig.5. Dynamic of indicators in test "Torso rising during 30 seconds"

Graphs, illustrating flexibility are given in fig. 6 and 7.

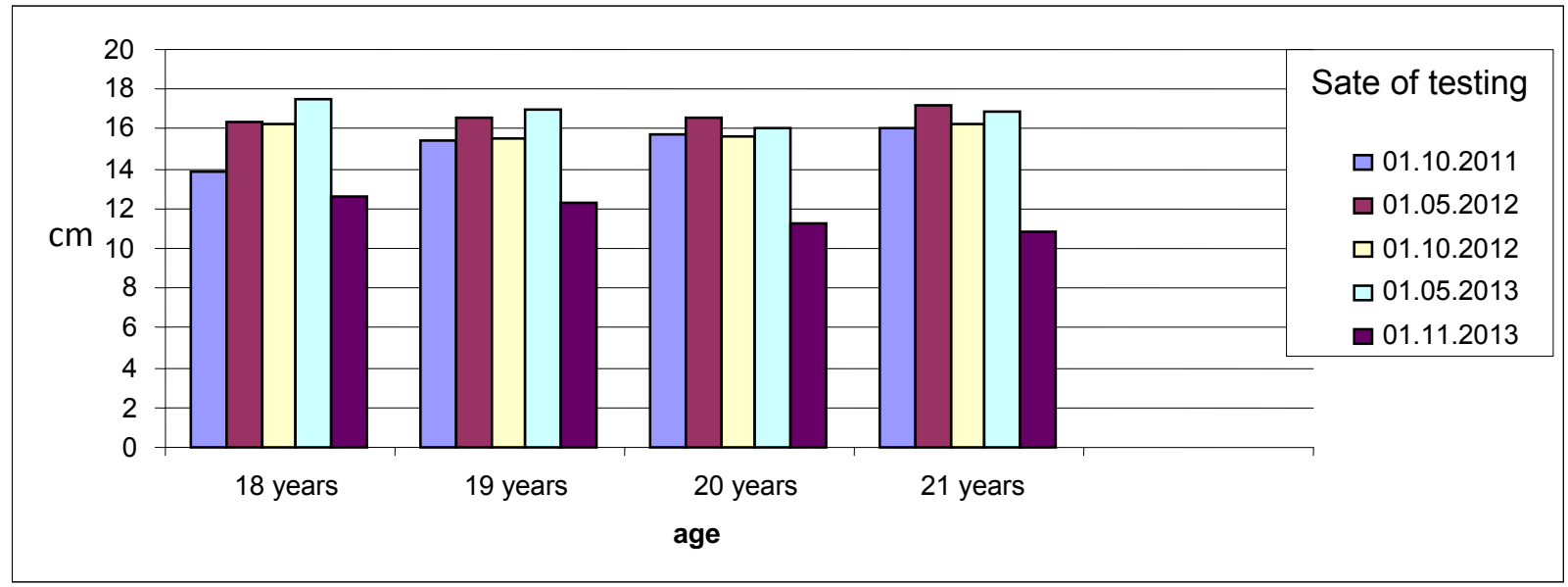

Fig. 6. Dynamic of indicators in test "Forward bending"

In these figures it is seen that in every age group there is confident dynamic: from first testing (October 2001) to May 2013 (when there were "twice a week" lessons. With passing to "once a week" lessons flexibility shows expressive dynamic of worsening in all age groups. With it, the highest reduction was registered in age 20 and 21 years old. It confidently reduced $(\mathrm{P}<0.05)$ in test "forward bending" in age 20 years old by $26.2 \%$, and in 21 years old age -35 . $9 \%$. In test "backward bending" from lying on abdomen position - by 19.5 and $24.4 \%$ (accordingly).

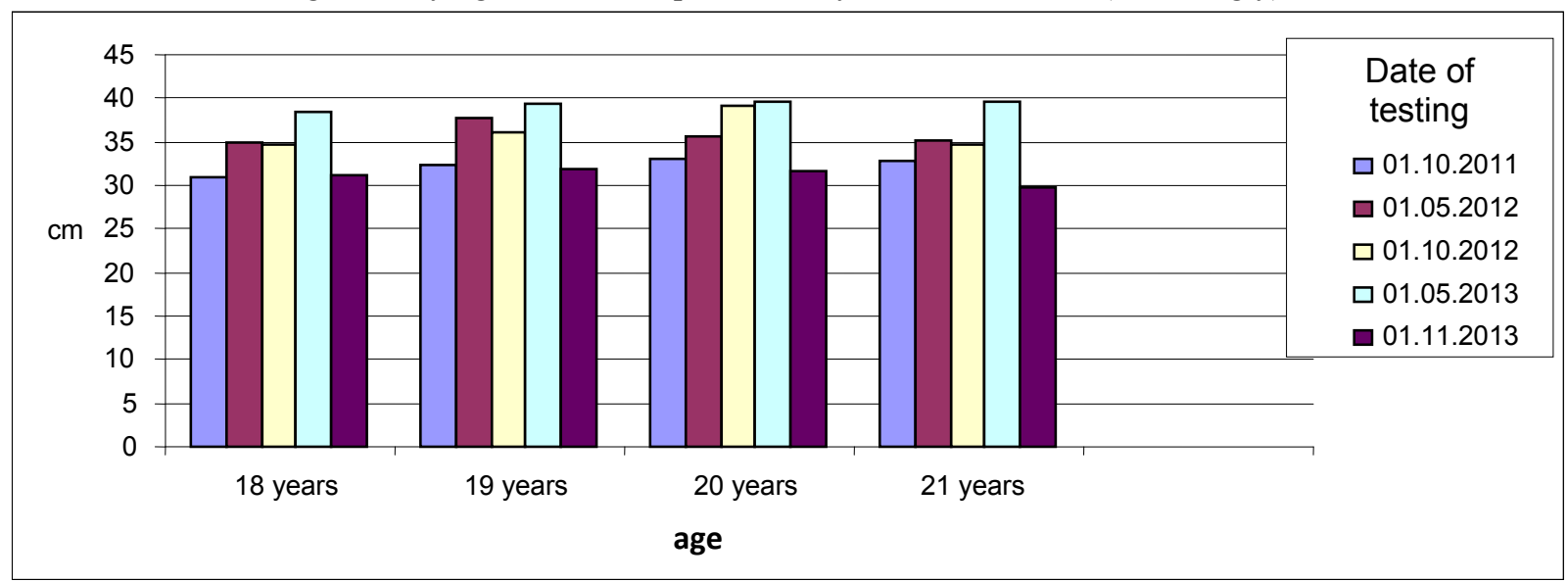

Fig.7. Dynamic of indicators in test "Backward bending from lying on abdomen position”. 
Dynamic of strength of lower limbs' muscles in test "long jump from the spot" is given in fig.8.

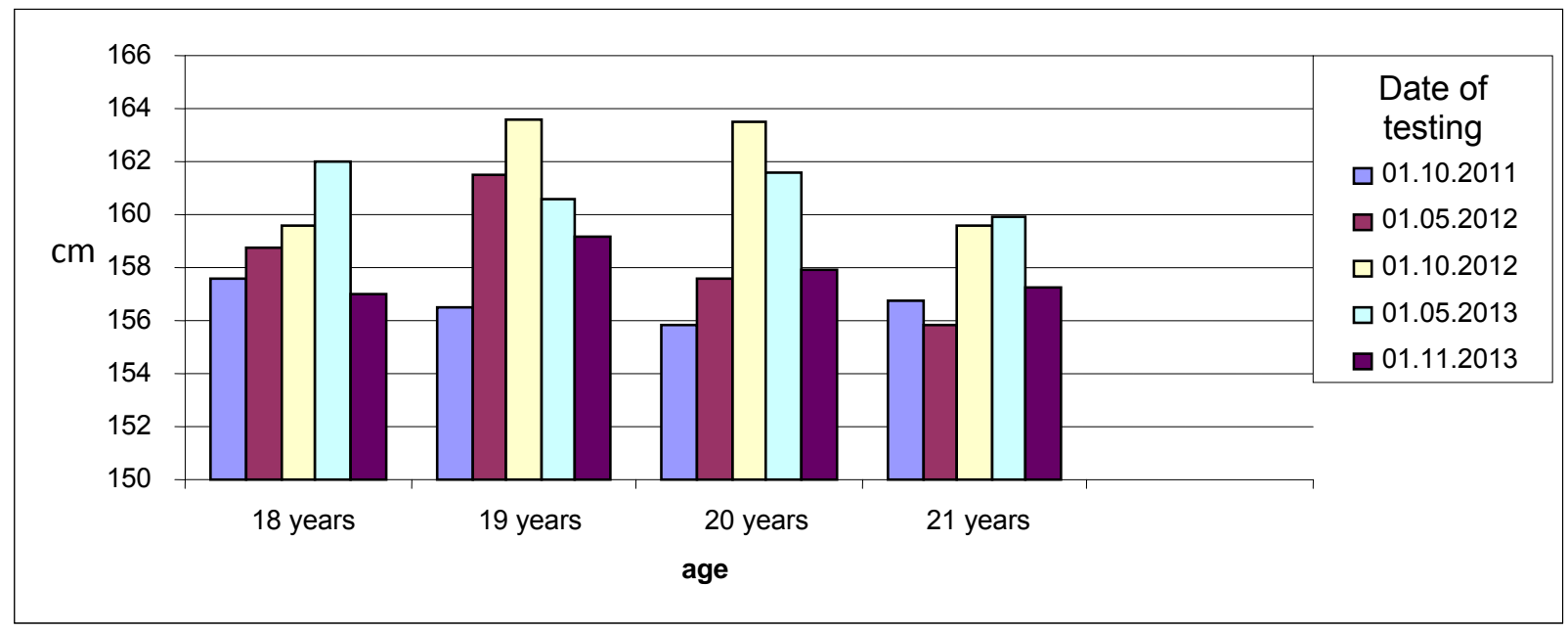

Fig. 8. Dynamic of indicators in test "Long jump from the spot"

We did not determine confident differences between indicators of all age girls with their testing in different dates. It can witness about insufficient effectiveness of used motion loads on lower limbs' muscles.

\section{Conclusions:}

1. Observation over age dynamic of physical fitness of special health group's girl students during 5 semesters permitted to determine positive dynamic in 5 from 8 motion tests by $5^{\text {th }}$ semester (with "twice a week" physical culture lessons). We did not register positive changes in general endurance of organism (100 meters' run), torso muscles' strength (test "torso rising during 30 seconds" and lower limbs (test "long jump from the spot").

2. With passing to "once a week" physical culture lessons (from $5^{\text {th }}$ semester) in all 8 tests we registered confident worsening of motion characteristics.

3. Monitoring of girl students' physical fitness can be regarded as a factor of increase of youth physical education's pedagogical orientation. The received results permitted to correct academic process; in particular to pay special attention to development of weak motion qualities with the help of appropriate physical exercises. Besides, with passing to "once a week" lessons it is recommended to use controlled independent trainings for maintaining of required physical condition with compulsory records in diary of self-control.

\section{References:}

1. Bakanova A. F. Formirovanie zdorovogo obraza zhiznedeiatel'nosti i problema individualizacii fizicheskoj podgotovlennosti studencheskoj molodezhi [Formation of healthy way of life and the problem of individualization of physical preparedness of students]. Physical Education of Students. 2012, no.1, pp. 8-12. (in Russian)

2. Bondarenko I.G. Opredelenie urovnia fizicheskoj podgotovlennosti studentov: dvigatel'nye testy i metod indeksov [Determining the level of physical preparedness of students]. Physical Education of Students. 2011, no.2, pp. 1013. (in Russian)

3. Borejko N.Iu. Razrabotka sistemy fizicheskogo vospitaniia dlia vysshikh tekhnicheskikh uchebnykh zavedenij [Development of physical education system for higher technical educational institutions]. Physical Education of Students. 2011, no.2, pp. 14-18. (in Russian)

4. Izaak S.I. [Scientific and technical project: monitoring of physical development and physical preparedness of children, adolescents and young]. Prioritety i perspektivy fizicheskoj kul'tury i massovogo sporta $v$ usloviiakh industrial'no-innovacionnogo razvitiia. Mat. konf. [Priorities and prospects for physical culture and sports in terms of industrial and innovative development. Conference]. Kazakhstan, Astana, 2013, pp. 171-174. (in Russian)

5. Kosolapov A.B., Lofitskaia V.A. Problemy izucheniia sokhraneniia i razvitiia zdorov'ia studentov [Problems of studying the preservation and development of students' health], Vladivostok, DVGAEU, 2002, 154 p. (in Russian)

6. Korolinskaia S.V. Nekotorye problemy adaptacii inostrannykh studentov anglijskogo otdeleniia NFaU [Some problems of adaptation of foreign students in the English Department of the University]. Physical Education of Students. 2011, no.4, pp. 48-51. (in Russian)

7. Lebedinskij V.Iu., Kolokol'cev M.M., Maslova E.S. Monitoring zdorov'ia sub"ektov obrazovatel'nykh processov v vuzakh [Health monitoring subjects of educational process in universities]. Irkutsk, Irkutsk State Technical University Publ., 2008, 268 p. (in Russian)

8. Semenov L.A. Monitoring kondicionnoj fizicheskoj podgotovlennosti $v$ obrazovatel'nykh uchrezhdeniiakh [Monitoring conditional of physical preparedness in educational institutions]. Moscow, Soviet sport, 2007,168 p. (in Russian) 
9. Solov'ev V.N. Adaptaciia studentov $k$ uchebnomu processu v vysshej shkole. Dokt. dis. [Adaptation of students to the educational process in higher education. Dokt. Diss.]. Izhevsk, 2003, 46 s. (in Russian)

10. Smirnov I.Iu. Fizkul'tura dlia special'noj medicinskoj gruppy [Physical education for special medical group]. Kostroma, Kostroma State Technological University Publ., 2012, 51 p. (in Russian)

11. Tiapin A.N., Puzyr' Iu.P., Zakharov L.A. Fizkul'turnyj pasport [Physical culture passport]. Moscow, 1998,25 p. (in Russian)

12. Shporin E.G., Lebedinskij V.Iu., Kolokol'cev M.M. [Monitoring the physical condition of students as an analytical database forming their healthy lifestyle]. Studencheskoe sportivnoe dvizhenie: Sostoianie, problemy i perspektivy razvitiia. Mat. mezhd. nauch.-prakt. konf. [Student sports movement: Status, problems and development prospects. Conference]. Krasnoyarsk, 2013, p. 479. (in Russian)

13. Abdullah A.S.M. Factors related to non-participation in physical activity among the students in Hong Kong. International Journal of Sports Medicine, 2005, vol.26, no.7, pp. 611-615.

14. Booth M.L. Assessment of physical activity: an international perspective. Research Quarterly for Exercise \& Sport, 2000, vol.71,no.2, pp. 114-120.

15. Fontes A.C.D, Vianna R.P.T. Prevalence and factors related to low level physical activity among university students in a public university in the northeast region of Brazil. Revista Brasileira de Epidemiologia, 2009, vol.12, no.1, pp. 20-29.

16. Haase A. Leisure-time physical activity in university students from countries: associations with health beliefs, risk awareness and national economic development. Preventive Medicine, 2004, vol.39, pp. 182-190.

17. Harkins S.W. Relationship between central and autonomic nervous system activity: Correlates of psychomotor performance in elderly men. Experimental Aging Research, 1976, vol.2, no.5, pp. 409-423.

18. Jorgensen M.M., Zachariae R. Autonomic reactivity to cognitive and emotional stress of low, medium, and high hypnotizable healthy subjects: Testing predictions from the high risk model of threat perception. International Journal of Clinical and Experimental Hypnosis, 2002, vol.50, no.3, pp. 248-275.

19. Musharrafieh U. Determinant of university students physical exercise: a study from Lebanon. International Journal of Public Health, 2009, vol.53, no.4, pp. 208-213.

20. Prusik Krzysztof, Prusik Katarzyna, Iermakov S.S., Kozina Zh.L. Indexes of physical development, physical preparedness and functional state of polish students. Pedagogics, Psychology, Medical-Biological Problems of Physical Training and Sports. 2012, no.12, pp. 113-122.

21. Quennerstedt M. Exploring the relation between physical activity and health - a salutogenic approach to physical education. Sport, Education and Society. 2008, vol.13, no.3, pp. $267-283$. http://dx.doi.org/10.1080/13573320802200594 
Information about the authors:

Prosvirina L.N.: http://orcid.org/0000-0002-2196-7400; mihkoll@mail. ru; National Research Irkutsk State Technical University; 83, Lermontov street, 664074, Irkutsk, Russia.

Kolokoltsev M.M.: http://orcid.org/0000-0001-6620-6296; mihkoll@ mail.ru; National Research Irkutsk State Technical University; 83, Lermontov street, 664074, Irkutsk, Russia.

Kolchanova M.A.: http://orcid.org/0000-0001-9775-4236; makolchanova@gmail.com; National Research Irkutsk State Technical University; 83, Lermontov street, 664074, Irkutsk, Russia.

Cieslicka Miroslawa: http://orcid.org/0000-0002-0407-2592; cudaki@ op.pl; Kazimierz Wielki University in Bydgoszcz; Chodkiewicza str. 30, 85-064 Bydgoszcz, Poland.

Stankiewicz Blazej: http://orcid.org/0000-0001-6743-1073; blazej1975@interia.pl; Kazimierz Wielki University in Bydgoszcz; Chodkiewicza str. 30, 85-064 Bydgoszcz, Poland.

Cite this article as: Prosvirina L.N., Kolokoltsev M.M. Kolchanova M.A., Cieslicka Miroslawa, Stankiewicz Blazej. The characteristic of the engine qualities of the students of technical institute of III functional health group (special medical group) Physical education of students, 2015, no.1, pp. 43-49. http://dx.doi. org/10.15561/20755279.2015.0107

The electronic version of this article is the complete one and can be found online at: http://www.sportpedu.org.ua/html/arhive-e.html

This is an Open Access article distributed under the terms of the Creative Commons Attribution License, which permits unrestricted use, distribution, and reproduction in any medium, provided the original work is properly cited (http:// creativecommons.org/licenses/by/3.0/deed.en)

Received: 27.11.2014

Accepted: 27.12.2014; Published: 30.12.2014 